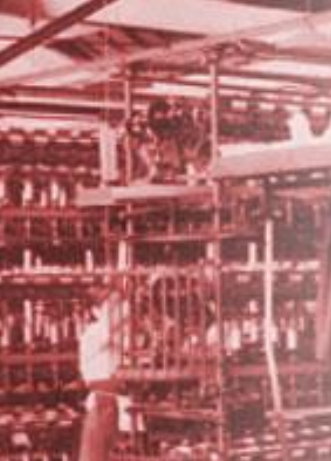

Vol. 4, No. 1 (2016)

\title{
Japanese Company Histories as Repositories of Tacit Knowledge ${ }^{1}$
}

\author{
Maureen Donovan \\ Ohio State University Libraries
}

In their book, The Power of Pull, John Hagel III, John Seely Brown, and Lang Davison discuss the increasing importance of tacit knowledge in today's world, as sources of economic value move away from "stocks" of old knowledge toward "flows" of new and emerging knowledge. Early stage "new knowledge," according to their analysis, has a higher tacit component in a rapidly changing context, and can best be accessed through networks of trust-based, long-term relationships in which participants share "know-how" with each other. Emphasizing that people carry that kind of "know how" with them, the authors of The Power of Pull note that, while online social networks and other virtual platforms are important ways of connecting, the best way to stay on top of new and emerging knowledge or research trends is to seek out conferences that "spring up to accommodate the desire of participants to share stories about their experiences with like-minded people." 2

The November 20, 2010 issue of Shūkan Tōyō Keizai 週刊東洋経済, a special issue commemorating 115 years of its publication, devoted its cover story, comprising some forty-five pages, to a survey of other Japanese companies that had also passed the one hundred year milestone. ${ }^{3}$ In a section of that cover story Kunisada Fumitaka advises readers to seek the kind of tacit knowledge needed to revive Japanese economic engines by reading histories of successful companies that survived for more than a century, "Company histories are treasure troves of business knowledge for turning point eras, such as the present. Read them!!"4

The apparent contrast between the recommendations of Shükan Töyō Keizai and of The Power of Pull could hardly be greater. The authors of The Power of Pull advocate traveling to conferences in pursuit of tidbits of new or emerging knowledge garnered through participation in discussions with trusted colleagues, while Kunisada Fumitaka recommends company histories, such as those in the Kanagawa Kenritsu Kawasaki Shimin Toshokan, whose shashi collection stacks were photographed for the article. Nonetheless, while Japanese company histories record stories of a company's founding, its milestones and past glories, their real focus is on the future, which is why they are abundant sources of tacit knowledge. Written to help employees and business associates understand the

\footnotetext{
${ }^{1}$ An earlier version of this paper was presented at the 2011 Shashi Group Workshop "Researching with Shashi: A Workshop on Using Japanese Company and Institutional Histories and Archives," as part of the AAS-ICAS Joint Conference, Hawaii Convention Center, Honolulu, March 31, 2011.

${ }^{2}$ John Hagel III, John Seely Brown, Lang Davison. The Power of Pull (New York: Basic Books, 2010) Kindle edition. loc: 1559.

3 “Ikei no Hyakunen Kigyō” 「異形の百年企業)、Shūkan Tōyō Keizai 週刊東洋経済 (November 20, 2010), 40-85.

4 Kunisada Fumitaka 国貞文隆, “Shashi wa ‘bijinesu chi’ no hōko, jidai no tenkanki no imakoso o yome!”「社史は「ビジネス知」の宝庫 、時代の転換期の今こそ読め!」, Shūkan Tōyō Keizai 週刊東洋経済 (November 20, 2010), 53-55.
} 
traditions and values of the company, shashi provide unique access into a company's culture. Ostensibly focused on the past, in fact they are intended to mobilize future achievements. Shashi are written to inspire workers to build capabilities for the future that draw on the achievements of the past. In preparing its corporate history a company is investing in its future!

In her writings about Japanese company histories, including her book Shashi no kenkyū, Murahashi Katsuko notes that shashi are useful for researching case studies, perhaps because they include just the kind of tacit knowledge that cannot be found elsewhere, preserving for posterity some of what The Power of Pull authors suggest can best be encountered in verbal exchanges at conference venues. 5

The Shūkan Tōyō Keizai issue presents research conducted by Gotō Toshio (後藤俊夫) on Japanese family businesses, including a chart comparing the number of family businesses that are over 200 years old in various countries around the world. Japan has 3,886; Germany is second with only half as many. Other countries have many fewer. Industries in which century-old Japanese family businesses abound include sake brewing, kimono fabrics, ryokan and so on. Gotō identifies deep roots in Confucian ethical philosophy as related significantly to the longevity of family firms, for example, noting that their products often cater to basic human needs and that the firms feel as much of an obligation to the local community as to their customers. ${ }^{6}$

Stories of individual companies comprise much of the Shūkan Tōyō Keizai cover story, organized around old fashioned slogans, as follows:

“Management drawing on the spirit from the company’s origins” (創業精神を生かす経営)

Shimazu Seisakujo (Shimadzu Corporation; founded 1875)

Idemitsu Kōsan (Idemitsu Kosan Corporation; founded 1911)

Shimizu Kensetsu (Shimizu Corporation; founded 1804)

Ajinomoto (Ajinomoto Corporation; founded 1909)

Toyota Jidōsha (Toyota Motor Corporation; founded 1894)

“Balance of tradition and innovation”（伝統と革新のバランス）

Nihon Seikōjo (The Japan Steel Works; founded 1907)

Shin Nihon Seitetsu (Nippon Steel Corporation; founded 1901)

Noritake (Noritake Company, Ltd; founded 1904)

Yuasa Shōji (Yuasa Trading Co., Ltd; founded 1666)

\footnotetext{
${ }^{5}$ Murahashi, Katsuko 村橋勝子. Shashi no Kenkyū 社史の研究. (Tokyo: Daiyamondo, 2002). See especially Chapter 1, part 4: “Shashi no miryoku”「社史の鬼力」、31-45.

${ }^{6} 3$ Gotō, Toshio 後藤俊夫. “Longevity of Japanese Family Firms, ” Handbook of Research on Family Business

(Cheltenham, UK ; Northampton, MA : Edward Elgar, c2006), 517.
} 
“Closely attached to the region while not moving headquarters away” (本拠を移さず地域未着)

Ube Kōsan (Ube Industries; founded 1897)

Chisso (Chisso Corporation; founded 1906)

Seren (Seiren Corporation; founded 1889)

“Management measuring people by their single-minded devotion.”（一意専心の身の丈経営）

Suzuki Baiorin Seizō (Suzuki Violin Co., Ltd; founded 1887)

Teikoku Seiyaku (Teikoku Seiyaku Co, Ltd; founded 1848)

With the bursting of real estate bubbles and the collapse of financial markets worldwide bringing widespread skepticism regarding the trustworthiness of quantitative data, qualitative inquiry is now taken more seriously. The appendices of shashi are rich in statistics, but the narrative portions of the books have their own value as primary sources as well. A well-known limitation of shashi is that the stories they tell are self- serving, extolling the feats of their founders and achievements over the years without any criticism. Controversies, mismanagement and malfeasance are generally whitewashed. Shashi are no more and no less than what they aspire to be, namely the story of a company as told by its own employees or by people the company hired to write it with their full cooperation. Those narratives can be used to derive insights into the past. Perhaps they can also be a stimulus for imagining the future.

\section{(c)) EY}

New articles in this journal are licensed under a Creative Commons Attribution 3.0 United States License.

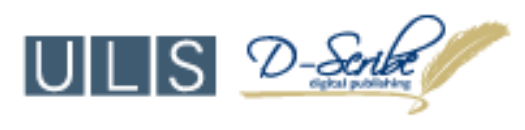

This journal is published by the University Library System, University of Pittsburgh as part of its D-Scribe Digital Publishing Program and is cosponsored by the University of Pittsburgh Press. 